\title{
SLANGA DAN SIMBOL TUMBUHAN DALAM KOMUNIKASI LISAN MASYARAKAT MELAYU: PENDEKATAN SEMANTIK INKUISITIF
}

\section{(SLANG AND PLANT SYMBOLS IN MALAY ORAL COMMUNICATION: INQUISITIVE SEMANTIC APPROACH)}

\author{
Muhammad Zaid Daud \\ Mary Fatimah Subet \\ Fakulti Bahasa dan Komunikasi \\ Universiti Malaysia Sarawak
}

\begin{abstract}
Abstrak
Dalam ilmu linguistik, slanga merupakan bahasa tidak formal yang mewakili kelompok sosial tertentu. Pembentukan kata slanga ini mampu membentuk makna yang tertentu mengikut penginterpretasian makna oleh kelompok sosial yang menggunakannya. Bagi mengutip data slanga yang dikehendaki pendekatan kualitatif diaplikasikan berdasarkan komunikasi lisan (secara tidak formal) dalam kalangan masyarakat Melayu. Seterusnya, data ditranskripsikan ke dalam bentuk transkripsi perbualan. Hasil daripada transkripsi perbualan tersebut pengkaji memperoleh 23 data slanga. Data slanga tersebut dapat dipecahkan lagi kepada empat domain yang khusus salah satunya ialah slanga dalam domain tumbuh-tumbuhan. Berdasarkan pensampelan bertujuan empat slanga yang mempunyai simbol tumbuhan telah dikenal pasti seperti 'patoh getoh', 'kunyah tebu', 'mat jambu' dan 'jua langsat'. Bagi menganalisis data tersebut pendekatan semantik inkuisitif oleh Nor Hashimah Jalaluddin (2014) serta dibantu dengan analisis Rangka Rujuk Silang (RRS) oleh Kempson (1986) diaplikasikan bagi mendapatkan maklumat tambahan kepada pengkaji dalam menghuraikan makna slanga tersebut. Oleh
\end{abstract}


itu, berdasarkan gabungan RRS dengan maklumat budaya mendalam mampu menghasilkan penghuraian makna sebenar sesuatu slanga sehingga ke akal budi penuturnya.

Kata kunci: Slanga, simbol tumbuhan, semantik, Rangka Rujuk Silang (RRS), semantik Inkuisitif, akal budi penutur.

\section{Abstract}

In the linguistic field, slang is an informal language that represents a particular social group. This slang formulation is able to form specific meanings as interpreted by the social groups that use it. To collect slang data required qualitative approach was applied based on verbal communication (informally) among the Malay community. Next, the data is transcribed into a transcript of the conversation. As a result of the transcript of the conversation the researcher obtained 23 slang data. The slang data can be further subdivided into four specific domains, one of which is the slang in the plant domain. Based on four-slang-based sampling with plant symbols identified, such as 'patoh getoh', 'kunyah tebu', 'mat jambu' and 'jua langsat'. To analyze the data, the inquisitive semantic approach by Nor Hashimah Jalaluddin (2014) and assisted Cross-reference Framework (CRF) analysis by Kempson (1986) was applied to provide additional information to the researcher in explaining the meaning of the slang. The combination of CRF with deep cultural information is capable of producing a description of the true meaning of a slang up to the mind of the speaker.

Keywords: Slang, plant symbol, semantic, Cross-Reference Framework $(C R F)$, inquisitive semantic, mind of the speaker.

\section{Pengenalan}

Brooke (1973), telah mengungkapkan bahawa variasi yang terdapat dalam sesuatu bahasa diberi beberapa nama oleh ahli-ahli bahasa berdasarkan faktor-faktor yang tertentu seperti, variasi atau ragam bahasa mengikut penggunaan sebagai register atau laras dalam ilmu sosiolinguistik. Menurut Brooke lagi variasi bahasa termasuklah slanga, 
dialek, diglosia dan idiolek. Slanga merupakan sejenis kosa kata yang tidak formal dalam bahasa, termasuklah dalam bahasa Melayu. Slanga dapat disifatkan sebagai mainan bahasa kerana penutur bebas menggunakan bahasa tanpa memikirkan kegramatisan sesuatu perkataan atau ayat tersebut sehingga ia dapat membentuk sesuatu makna yang baharu ataupun berlainan daripada makna asalnya (Muhammad Zaid Daud, 2018). Menurut Ajid Che Kob (1998) pula, kata kunci dalam pengujaran bahasa slanga ini mempunyai ciriciri uniknya tersendiri, kerana mampu untuk menguatkan dan mengetengahkan identiti kelompok sosialnya.

Bagi Mhd. Amin Arshad (2000) dalam (Mary Fatimah Subet \& Muhammad Zaid Daud, 2016) telah menyenaraikan sebanyak lima belas ciri wujudnya penggunaan bahasa slanga dalam kalangan kelompok masyarakat, iaitu: (1) untuk tujuan hiburan (suka-suka), (2) sebagai latihan untuk menguji kecerdasan, kemahiran atau kebolehan untuk menimbulkan suasana jenaka, (3) untuk menonjol diri sebagai perintis, (4) untuk memperindah pertuturan dan mewarnakan suasana supaya menjadi lebih mesra dan hidup, (5) untuk menarik perhatian orang lain, (6) untuk mengelakkan "klise" atau tujuan penyingkatan tanpa menjejaskan makna, (7) untuk menggayakan bahasa, (8) untuk merumitkan sesuatu yang konkrit kepada yang abstrak, sesuatu yang bersifat jelas kepada yang samarsamar, (9) untuk mengurangkan suasana su gul dan kerisauan dalam perbualan, (10) untuk mengurangkan suasana yang sedih dan serius, (11) untuk tujuan bergurau senda, (12) untuk melicinkan sesuatu perhubungan sosial, (13) untuk mengakrabkan lagi persahabatan yang sedia terjalin, (14) untuk menunjukkan bahawa seseorang itu terdiri daripada satu aliran atau golongan kelas sosial yang sama, dan (15) untuk merahsiakan sesuatu agar orang lain tidak memahaminya.

Dapat dirumuskan bahawa, slanga merupakan bahasa yang tidak formal dan dituturkan dalam sesuatu kelompok masyarakat mahupun, ahli kumpulan minoriti. Namun begitu, penggunaan slanga ini boleh merebak keluar daripada kelompok asalnya sehingga mudah difahami oleh kelompok yang lain (Siti Hajar Abdul Aziz, 2009). Komuniti yang menuturkan dalam suatu bahasa, slanga mampu melangkaui batas sosial, etnik, ekonomi dan kawasan geografinya. Slanga memiliki 
ciri-ciri unik dalam bentuk ungkapan dan pengujaran sehingga akhirnya bahasa slanga ini menjadi sangat sinonim, akrab dan berakar umbi untuk membentuk identiti kumpulan (Asmah Haji Omar, 1993). Hal ini disebabkan oleh, penggunaan slanga dalam komunikasi lisan, bertujuan untuk merahsiakan, melembutkan atau menghaluskan tutur kata mereka supaya tidak menimbulkan perasan amarah mahupun buruk sangka daripada kelompok dalam dan luar komuniti tersebut.

\section{Objektif Kajian}

Secara khususnya, objektif kajian ini adalah untuk menghuraikan makna sebenar dalam pembentukan perbendaharaan kata slanga (simbol tumbuh-tumbuhan) dalam kalangan masyarakat Melayu. Bagi mencapai objektif kajian ini analisis berpandukan pendekatan semantik inkuisitif oleh Nor Hashimah Jalaluddin (2014) serta dibantu dengan analisis Rangka Rujuk Silang (RRS) oleh Kempson (1986).

\section{Sorotan Kajian Lepas}

Pada bahagian ini pengkaji akan menyorot dua pengkajian daripada sarjana lepas yang melibatkan pengkajian slanga dari pelbagai sudut perspektif dan seterusnya pengkajian mengenai pendekatan semantik inkuisitif. Melihat kepada kedua-dua aspek ini merupakan pembacaan autentik kerana aspek slanga dan semantik inkuisitif merupakan inti pati khusus pada kajian ini.

Kajian mengenai slanga telah banyak dijalankan oleh sarjana yang lepas sama ada di dalam mahupun luar negara dengan pelbagai perspektif kajian linguistik khususnya seperti, pragmatik, semantik, sosiolinguistik, morfologi, sintaksis dan sebagainya. Antara sarjana lepas yang menjadikan slanga sebagai dapatan kajian mereka ialah Arua \& Modupe (2009), Sara Hashemi Shahraki \& Abbass Eslami Rasekh (2011), Tay (2011), Zhou \& Fan (2013), Nadiah Suboh (2013), Kheren Kazia Adolof (2014), Aboh (2015), Setiawan Nugroho (2015), Mary Fatimah Subet \& Muhammad Zaid Daud (2016, 2017, 2018) serta Muhammad Zaid Daud (2017, 2018c). Dengan itu, kajian-kajian tersebut telah menjadi panduan kepada pengkaji 
dalam menyorot isu-isu berkaitan dengan slanga yang telah menjadi inti kepada kajian ini.

Kajian Aboh (2015), mendapati bahawa penulis novel di Nigeria telah menggunakan slanga untuk mengekspresikan perasaan terbuka mereka mengenai seks dan tajuk yang berkaitan dengannya. Tajuk yang berkaitan dengan seks di negara tersebut dianggap sebagai tabu dan tidak patut dibicarakan secara terbuka. Kajian ini menggunakan pendekatan kualitatif iaitu analisis dokumen yang telah dibukukan. Data slanga bagi kajian ini diperoleh daripada novel yang bertajuk Helon Habila's Waiting for an Angel, Vincent Egbuson's Love My Planet, Abimbola Adelakun's Under the Brown Rusted Roofs dan Okey Ndibe's Arrows of Rain. Salah satu data slanga bagi kajian ini, ialah kata $A$ gun di mana makna konseptualnya adalah merujuk pistol jika diterjemahkan secara harfiah, namun implisitnya kata tersebut merujuk kepada alat sulit lelaki. Berasosiasi dengan dapatan kajian Mary Fatimah Subet dan Muhammad Zaid Daud (2018) juga, mendapati bahawa terdapat penggantian leksikal iaitu pacat bagi merujuk kemaluan lelaki dalam slanga pelacur.

Indrawati Zahid (2012) dalam rencana yang bertajuk Bahasa Melayu Terpinggir dalam Media Baharu telah membincangkan mengenai isu keterpinggiran bahasa Melayu di dalam media terutamanya internet. Kajian ini, telah menjelaskan bahawa keterpinggiran bahasa dalam media seperti internet ini dapat diklasifikasikan kepada dua perkara iaitu kurangnya frekuensi penggunaan bahasa Melayu dan kualiti penggunaan bahasa Melayu yang amat rendah dengan wujudnya campur aduk bahasa asing, singkatan mahupun slanga dapat menyebabkan terpinggirnya bahasa Melayu dalam media internet tersebut. Selain itu, terdapat juga kajian slanga yang menyentuh aspek morfologi dan sintaksis seperti kajian Mary Fatimah Subet \& Muhammad Zaid Daud (2016), memperlihatkan pembuktian penggunaan slanga mampu menjadi kata penguat dalam bahasa Melayu yang dipertuturkan oleh rakyat Malaysia. Kajian tersebut dijalankan terhadap 360 orang responden dan mendapati bahawa istilah giler merupakan slanga yang bertindak sebagai kata penguat bebas dalam bahasa Melayu seperti sungguh, amat dan sangat. 
Walau bagaimanapun, berdasarkan sorotan kajian lepas daripada pengkajian slanga ini, lebih memfokuskan perubahan makna konseptualnya kepada pembawaan makna implisit sesuatu leksikal. Oleh itu, bagi kajian ini, pengkaji akan mengaplikasikan pendekatan semantik inkuisitif oleh Nor Hashimah Jalaluddin (2014) dengan menggunakan slanga sebagai dapatan kajiannya. Hal ini disebabkan oleh, kajian yang mengaplikasikan pendekatan ini hanya memfokuskan data kajian seperti peribahasa dan cerita lipur lara seperti kajian Nor Hashimah Jalaluddin (2014a; 2014b; 2015), Suriati Zakaria \& Nor Hashimah Jalaluddin (2015), Nur Afiqah Wan Mansor \& Nor Hashimah Jalaluddin (2015; 2016), Jun aini Kasdan, Nor Hashimah Jalaluddin \& Wan Nurasikin Wan Ismail (2016), Muhammad Zaid Daud (2017; 2018a; 2018b), Tangaprabu Murthy dan Mary Fatimah Subet (2018a, 2018b), Tangaprabu Murthy, Mary Fatimah Subet dan Muhammad Zaid Daud (2019) serta Muhammad Zaid Daud dan Mary Fatimah Subet (2019a, 2019b).

Pengkajian slanga yang melibatkan semantik inkuisitif masih lagi kurang dijalankan oleh sarjana-sarjana sama ada dalam mahupun luar negara. Menurut Nor Hashimah Jalaluddin (2014a) telah menyatakan bahawa banyak aspek perlu dilihat agar bahasa tersebut segar dan kekal relevan. Tugas semantik inkuisitiflah yang perlu menjawab persoalanpersoalan tersebut berdasarkan maklumat konteks dan budaya yang melingkungi masyarakat penutur harus dipadukan bagi mencungkil falsafah di sebalik makna yang hendak disampaikan. Hal ini demikian kerana pengkaji-pengkaji lepas tidak menyentuh makna slanga ini menggunakan analisis semantik inkuisitif. Kajian mereka cukup sekadar mengetahui makna eksplisit dan implisit bagi sesuatu ujaran atau perkataan slanga itu sahaja tetapi, tidak pula mereka cuba meneroka makna sebenar di sebalik sesuatu slanga itu sehingga ke akal budi penuturnya.

Dalam masa yang sama, pengkaji-pengkaji lepas juga tidak mempersoalkan kenapa objek dan imej bagi sesuatu perkataan itu dipilih bagi mewakili sesuatu slanga. Contohnya, kajian Zuraidah Mohd Sulaiman, Gan Kiat Chien, Eng Sze Boon \& Ahmad Harith Syah Md Yusuf (2012). Pengkaji memetik salah satu daripada datanya iaitu, kencing tak tos yang membawa kepada makna eksplisit tidak tos 
(menapis/tapis) semasa buang air kencing atau makna sebenar bagi slanga tersebut adalah budak hingusan/setahun jagung. Berdasarkan data tersebut, pengkaji sebelum ini menginterpretasikan makna berdasarkan semantik skrip dan semantik resonans sahaja. Hal ini demikian kerana semantik skrip hanya melibatkan makna setara yang hanya bersifat harfiah dan pada peringkat kognitif penutur sahaja manakala, semantik resonans pula hanya melibatkan data, teori dan kognitif penutur sahaja (Nor Hashimah Jalaluddin, 2014b). Oleh itu, kajian ini bukan sahaja dapat membuka lembaran baharu kepada bidang pengkajian slanga malahan juga bidang kajian semantik inkuisitif juga kerana sebelum ini hanya memfokuskan kepada data-data peribahasa sahaja.

\section{Metodologi Kajian}

Data slanga ini telah dikutip dan dikumpul daripada kajian lapangan menerusi rakaman informan secara tidak formal serta catatan transkripsi perbualan. Susur galur prosedur menganalisis data bagi kajian secara tiga peringkat seperti yang terdapat pada rajah 1 .
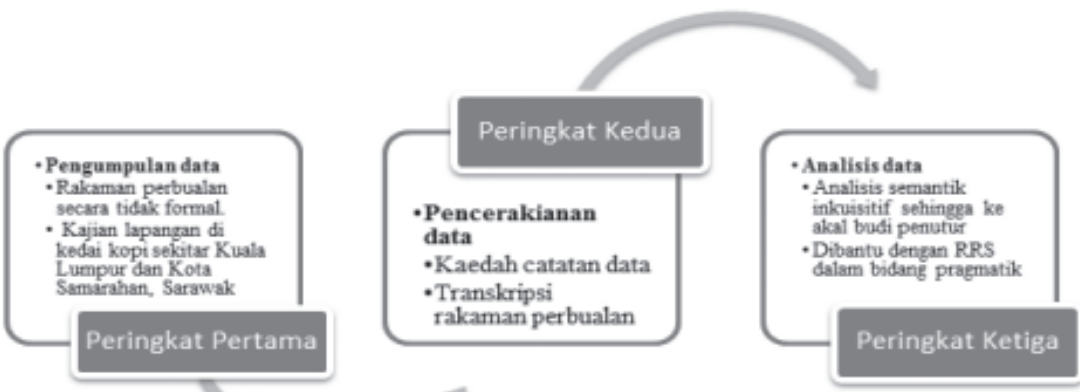

Rajah 1: Prosedur menganalisis data.

Kajian ini menganalisis slanga dalam perbualan di 6 buah kedai kopi sekitar Kuala Lumpur dan Kota Samarahan, Sarawak. Semasa aktiviti pengumpulan data satu rakaman perbualan secara tidak formal telah dilakukan bagi mendapatkan data kajian. Melalui kaedah rakaman perbualan secara tidak formal ini juga pernah dijalankan oleh sarjana lepas dalam kajian mereka seperti Gan (2000) dan Muhammad Zaid Daud (2017). Hasil dapatan data daripada rakaman perbualan 
secara tidak formal bertujuan untuk mendapatkan data yang lebih asli dan mudah diperoleh, iaitu tidak melibatkan unsur-unsur formaliti dalam perbualan. Walaupun, kajian ini melibatkan rakaman perbualan secara tidak formal pengkaji terlebih dahulu meminta kebenaran informan bagi merakam perbualan tersebut dan akan digunakan sebagai dapatan kajian ini, namun masa rakaman tersebut dibuat, pengkaji tidak memaklumkan kepada informan.

Sebanyak 9 rakaman perbualan telah diperoleh tetapi, tidak semua rakaman perbualan tersebut mengandungi slanga yang berasosiasi dengan tumbuh-tumbuhan/buah-buahan yang dikehendaki oleh pengkaji. Selepas penyaringan data terdapat 3 transkripsi perbualan yang mengandungi slanga yang berasosiasi dengan tumbuhtumbuhan/buah-buahan. Pemilihan data ini berdasarkan pensampelan bertujuan (purposive sampling), iaitu pengkaji memilih sampel berdasarkan kesesuaiannya untuk memenuhi objektif kajian.

Selepas selesai rakaman data diperoleh, perbualan secara spontan ini telah dimainkan semula oleh pengkaji untuk mendengar semula perbualan dengan teliti dan kemudiannya ditranskripkan ke dalam bentuk tulisan. Oleh sebab kebanyakan rakaman perbualan ini dipertuturkan dalam bahasa Melayu dan ada juga sebilangan data yang diperoleh pengkaji dalam bahasa Inggeris dan dialek Melayu Kelantan/Sarawak, pengkaji telah membahagikan bahasa-bahasa dan dialek ini kepada beberapa bentuk tulisan. Hal ini bertujuan untuk membezakan antara bahasa standard dengan bahasa lain mahupun bahasa dengan dialek yang lain. Berikut merupakan bentuk tulisan yang telah dibahagikan oleh pengkaji dalam transkripsi tersebut:
a) Bahasa Melayu: Huruf biasa
b) Bahasa Inggeris: Huruf Italics
c) Dialek Melayu Kelantan/Sarawak: Huruf bergaris
d) Ujaran Slanga: Huruf tebal dan bergaris

Pada peringkat ketiga merupakan peringkat penganalisisan data. Pada peringkat ini pendekatan semantik inkuisitif telah diterapkan berdasarkan data slanga-slanga tersebut. Pada bahagian ini, RRS juga dilakukan bagi membolehkan dua ayat yang tidak mempunyai rujukan 
khusus tetapi bantuan anteseden dan maklumat tambahan dapat digunakan berdasarkan konteks yang dibekalkan dalam ayat itu sendiri (Nur Afiqah Wan Mansor \& Nor Hashimah Jalaluddin, 2015). Sebelum mencapai kepada tahap semantik inkuisitif ini wujudnya semantik skrip dan semantik resonans terlebih dahulu. Walau bagaimanapun, semantik skrip dan semantik resonans tidak mencapai tahap sebenar yang ingin disampaikan oleh penutur kepada pendengar. Hal ini disebabkan semantik skrip hanya melibatkan makna setara yang hanya bersifat harfiah dan pada peringkat kognitif penutur sahaja manakala, semantik resonans pula hanya melibatkan data, teori dan kognitif penutur sahaja. Rajah 2 akan menerangkan susur galur kerangka semantik inkuisitif yang telah diringkaskan oleh Nor Hashimah Jalaluddin (2014a).

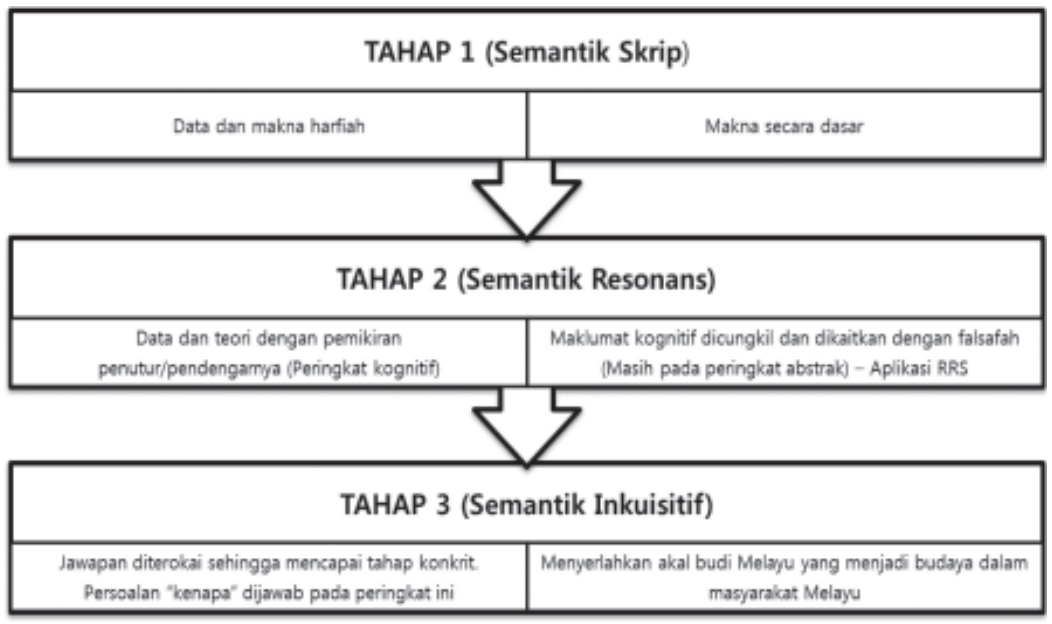

Rajah 2: Susur Galur Kerangka Semantik Inkuisitif.

Oleh sebab itu, jika dibandingkan dengan semantik skrip dan semantik resonans, semantik inkuisitif merupakan yang terkini dalam menilai makna yang sebenar yang hendak disampaikan oleh penutur. Semantik skrip yang hanya terhad kepada pengamatan dan andaian lalu. Dengan membuat andaian lalu membentuk tafsiran makna secara tersurat, manakala semantik rasonans pula menambah baik dengan mengambil kira data, teori, dan kognitif secara tersirat. Oleh yang demikian, semantik inkuisitif telah memartabatkan satu tahap yang 
lebih tinggi dan mendalam lagi sehingga ke peringkat akal budi Melayu (Nor Hashimah Jalaluddin, 2014a).

Kajian ini menggunakan ungkapan slanga dalam perbualan di kedai kopi menggunakan kaedah semantik inkuisitif dan seterusnya akan menyingkap makna sebenar yang tersirat dalam perihal makna slanga bersifat implisit itu. Semantik inkuisitif bukan sahaja dapat mencungkil falsafah dan akal budi Melayu tetapi juga tersirat ilmu yang bersifat multidisiplin di dalamnya. Antara bidang multidisiplin yang merentas bidang bahasa melalui semantik inkuisitif adalah seperti ilmu geografi, sejarah, etimologi, budaya, agama, sains, sosiologi dan sebagainya (Muhammad Zaid Daud, 2018a). Kepelbagaian bidang multidisiplin yang ditonjolkan daripada penerokaan makna peribahasa menggunakan pendekatan semantik inkuisitif merupakan satu kelebihan dalam usaha menambahkan ilmu pengetahuan yang dilihat tidak terhad kepada satu bidang tertentu sahaja (Mohd Ridzuan Md Nasir dan Mary Fatimah Subet, 2019).

\section{Dapatan Data}

Terdapat empat slanga yang berasosiasi dengan tumbuh-tumbuhan/ buah-buahan yang terdiri daripada kata getah, tebu, jambu dan langsat yang telah dikumpul oleh pengkaji berdasarkan transkripsi perbualan di KK ini. Berikut merupakan slanga di KK yang berasosiasi dengan tumbuh-tumbuhan/buah-buahan berserta makna mudahnya dan nama saintifik bagi data itu.

Jadual 1: Simbol tumbuhan dalam slanga

\begin{tabular}{|c|c|c|c|c|}
\hline No. & Slanga & Makna Mudah & $\begin{array}{l}\text { Simbol } \\
\text { Tumbuhan }\end{array}$ & $\begin{array}{l}\text { Nama } \\
\text { Saintifik }\end{array}$ \\
\hline 1. & Patoh getoh (DMK) & Mati pucuk (Bagi lelaki) & Getah & $\begin{array}{l}\text { Hevea } \\
\text { brasiliensis }\end{array}$ \\
\hline 2. & Kunyah tebu & Makan tidak kenyang-kenyang & Tebu & Saccharum \\
\hline 3. & Mat Jambu & $\begin{array}{l}\text { Lelaki yang mempunyai } \\
\text { perwatakan/rupa paras menarik }\end{array}$ & Jambu & $\begin{array}{l}\text { Syzygium } \\
\text { aqueum }\end{array}$ \\
\hline 4. & Jua Langsat (DMK) & Singgah merata-rata tempat & Langsat & $\begin{array}{l}\text { Lansium } \\
\text { domesticum }\end{array}$ \\
\hline
\end{tabular}


Oleh sebab itu, data-data slanga seperti patoh getoh, kunyah tebu, mat jambu dan jua langsat akan dibincangkan pada bahagian ini melalui pendekatan semantik inkuisitif yang diperoleh daripada transkripsi perbualan. Dalam pada itu, pengkaji turut memperoleh data daripada Dialek Melayu Kelantan (DMK) semasa mentranskripsikan dialog perbualan di KK walaupun data tersebut dalam DMK tidak mencacatkan dapatan kajian yang akan dianalisis dengan menggunakan pendekatan SI dengan kesinambungan RRS.

\section{Analisis dan Perbincangan}

Analisis data slanga berdasarkan dapatan kajian yang dikemukakan sebelum ini dianalisis dalam bahagian ini. Sehubungan dengan itu, bagi menjaga privasi informan, pengkaji tidak meletakkan nama penuh informan tetapi hanya menggantikannya dengan HURUF ABJAD sahaja. Hal ini demikian kerana terdapat dalam rakaman perbualan tersebut mengandungi perbualan yang dianggap sulit bagi pengkaji dan informan. Semasa pengkaji turut serta dalam perbualan tersebut pengkaji akan meletakkan huruf abjad seperti $\mathrm{Z}$ pada transkripsi perbualan tersebut.

\section{Slanga: Patoh Getoh (Dmk)}

Lokasi: Warung Kopi Abe Salleh, Kuala Lumpur

$\mathrm{J}:$... dok main denge anok ore jah, tok se ado anok sendiri ko?

K: Tau. Nanti-nanti kot.

B: Hoo la. Tapi kalu doh buleh anok sendiri. Happy sikit. (Ketawa)

$\mathrm{J}$ : ... Mek nok tanye nim. Tok soh nok maroh. Betol ko tok laki mu tu patoh getoh? Sebab tuh payoh nok bui anok ko demo?

B: Mu ni! Mulut tu. Tok soh jadi mulut beruh sangat la. Dok fikir perasaan ore tu. Doh ore tak dop rezeki buleh anok. Oyap gitu pulok.

\section{Analisis Semantik}

$\mathrm{J}:$... Mek nok tanye nim. Tok soh nok maroh. Betol ko tok laki mu tu patoh getoh? Sebab tuh payoh nok bui anok ko demo? 
Bentuk logik:

(1) : ... Mek nok tanye nim. Tok soh nok maroh. Betol ko tok laki mu tu

Sebab tuh payoh nok bui anok ko demo?

[mati pucuk]

Makna mudah bagi slanga yang berasosiasi dengan tumbuhtumbuhan/buah-buahan, iaitu patoh getoh (DMK) adalah lelaki yang mengalami masalah untuk mencapai ereksi sepenuhnya ketika hendak melakukan hubungan kelamin.

\section{Analisis Semantik Inkuisitif}

Berdasarkan bentuk logik yang telah dibincangkan pada analisis semantik tadi telah membawa makna slanga patoh getoh (DMK) kepada makna sebenar yang hendak disampaikan oleh penutur kepada pendengar. Pada peringkat analisis semantik melalui bentuk logik sesuatu ujaran telah memberikan makna implisit bagi slanga patoh getoh (DMK) yang membawa maksud lelaki yang tidak mencapai ereksi sepenuhnya ketika hendak melakukan hubungan kelamin. Pemberian makna slanga ini berdasarkan bentuk logik analisis semantik sebentar tadi. Pada masa yang sama konsep dan makna slanga boleh diteliti melalui transkripsi perbualan sebagai data utama seperti merujuk Junaini Kasdan \& Nor Hashimah Jalaluddin (2015) dengan menggabungkan data dan pendekatan RRS daripada sudut proses kognitif yang dapat dihuraikan makna sesuatu ujaran itu dengan lebih berpada. Berikut merupakan data penggunaan slanga patoh getoh $(D M K)$ yang terdapat dalam transkripsi perbualan di KK melalui pendekatan RRS.

Betol ko tok laki mu tu ***patoh getoh"**? Sebab tuh payoh nok bui anok ko demo.

Sebelum huraian yang lebih mendalam mengenai slanga tersebut pengkaji akan menterjemahkan ujaran tersebut kepada BMS terlebih dahulu untuk tujuan pemahaman pembaca yang tidak mahir dengan DMK. Ujaran tersebut adalah seperti berikut Betul ke suami kamu tu patah getah (slanga)? Sebab tu susah nak beri anak kepada kamu? Oleh itu, dalam frasa tok laki (suami) yang merujuk kepada lelaki/suami dan 
sebab tu payoh nok bui anok ko demo? (Sebab tu susah nak beri anak kepada kamu?) telah menjadi maklumat tambahan yang boleh membantu pembaca memahami maksud sebenar slanga yang hendak disampaikan kepada penutur sebagai gagal memberikan zuriat kepada rakannya itu. Walau bagaimanapun, wujudnya persoalan kenapakah penutur menggunakan istilah patoh getoh $(D M K)$ bagi merujuk seorang lelaki yang tidak mencapai ereksi sepenuhnya ketika hendak melakukan hubungan kelamin atau makna istilah perubatannya dikenali sebagai mati pucuk atau erectile dysfunction. Oleh itu, bukti kukuh analisis semantik inkuisitif dapat menjelaskan metafora di sebalik penggunaan slanga tersebut seperti persoalan-persoalan di atas tadi. Di sini dari sudut semantik inkuisitif wujud persoalan kenapa perlu diterokai hingga menemukan jawapan yang dapat menonjolkan akal budi penutur (Nur Afiqah Wan Mansor \& Nor Hashimah Jalaluddin, 2016). Dengan itu, pengkaji akan menghuraikan satu persatu makna literal bagi dua leksikal slanga ini patoh getoh (DMK) iaitu patoh (patah) dan getoh (getah) dan seterusnya akan dihuraikan berdasarkan pendekatan SI untuk melihat kesinambungan slanga patoh getoh ini dengan masalah seorang lelaki gagal untuk mencapai ereksi sepenuhnya ketika hendak melakukan hubungan kelamin.

Kata patah menurut Kamus Dewan Edisi Keempat (2015) adalah putus (bukan barang yang keras dan panjang), tidak bertaut atau bercantum kuat, manakala kata getah pula merupakan bahan kenyal atau diperbuat daripada susu getah. Hal ini sangat berkaitan dengan anggota kelamin lelaki yang tidak mampu mencapai ereksi sepenuhnya kerana seperti kata patah merujuk kepada hal yang tidak kuat atau keras dan ditambah lagi dengan anteseden getah sebagai objek tambahan bagi slanga tersebut. Dapat dilihat bahawasanya bahasa kiasan tidak akan lari daripada unsur alam dan budaya kerana bahasa kiasan itu sendiri lahir menerusi pengamatan dan pengalaman hidup sesuatu masyarakat yang diciptanya daripada unsur alam dan sering ditemui dalam bahasa kiasan dengan menggunakan tumbuhan sebagai objek pembayang kata (Nor Hashimah Jalaluddin, 2015) seperti mana slanga ini diujarkan. 
Berdasarkan kesinambungan slanga patoh getoh (DMK) ini dapat dikaitkan dengan masalah sakit tuan dari sudut sains perubatan adalah bertepatan dengan konteks ayat tersebut. Hal ini demikian kerana sakit tuan yang didefinisikan oleh Mohd Ismail Tambi (1995) dalam (Mohd Faisal Musa, 2014), sebagai penyakit dan masalah fungsi yang terdapat pada anggota reproduksi lelaki. Dalam hal ini, penyakit tersebut boleh berlaku pada zakar, buah zakar, kerandut buah zakar dan anggota lain yang berkaitan. Antara masalah yang sering dirujuk dalam konteks mati pucuk adalah seperti gangguan ereksi, masalah ketegangan zakar, dan lambat atau cepat ejakulasi. Penjelasan Mohd Ismail Tambi tersebut turut disokong oleh European Association of Urology (EAU) yang menyatakan bahawa sakit tuan lazimnya merujuk kepada masalah mati pucuk atau istilah perubatannya erectile dysfunction dan premature ejaculation (Wespes et al. 2002). Seperti yang telah dijelaskan sebentar tadi bahawa mati pucuk berkaitan gangguan ereksi, masalah ketegangan zakar, dan lambat atau cepat ejakulasi. Merujuk kembali frasa sebab tu payoh nok bui anok ko demo? (Sebab tu susah nak beri anak kepada kamu?) daripada RRS telah mempertalikan slanga patoh getoh (DMK) ini dengan masalah mati pucuk kerana masalah yang kelihatan hampir sama dengan masalah sakit tuan seperti ketidaksuburan sperma yang mengakibatkan berlakunya kemandulan. Menurut Inhorn (2004) kemandulan didefinisikan sebagai kegagalan memperoleh anak selepas setahun atau lebih selepas berusaha, sehingga mengakibatkan berlakunya ketiadaan anak tanpa rela (involuntary childlessness). Dalam konteks ini menurut Mohd Faisal Musa (2014) kemandulan lelaki berlaku kerana jumlah benih yang sedikit pada air mani (oligospermia), mutu benih yang tidak sihat pada air mani (asthenospermia), kecacatan benih pada air mani (teratospermia) dan ketiadaan benih pada air mani apabila dipancutkan (azoospermia). Kemandulan tidak semestinya bermaksud penghidapnya mengalami sakit tuan seperti mati pucuk dan ejakulasi pra-matang; malah kajian yang ada memaparkan lelaki mandul mempunyai kehidupan seks yang normal dan baik. Dapat disimpulkan di sini bahawa, pemilihan leksikal patoh (patah) dan getoh (getah) adalah sangat tepat bagi penutur bagi membuktikan suami kepada rakannya itu mengalami masalah sakit tuan kerana gagal memberikan zuriat kepada rakannya itu seperti mana yang telah dibincangkan dengan panjang lebarnya sebentar tadi. 


\section{Slanga: Kunyah Tebu}

\section{Lokasi: Kedai Kopi Haji Man, Kuala Lumpur}

Z: Aku nak oder makan tadi. Tapi tunggu kau. Lambat. Aku soh (suruh) diaorang tu tunggu. Kau nak makan apa? Haha (gelak) aku belanja.

R: Weh. Bakal pengantin nak belanja makan la.

Z: Arhh cepat la. Lapar ni.

R: Ah kau. Makan cam orang kunyah tebu ja. Makan buang. Makan buang. Tak kenyang-kenyang. Kang tak muat baju kahwin nanti. Baru kau tahu. Sebab dah gemuk. Diet lah kau.

Z: Tak pe. Gemuk-gemuk aku pun de orang sayang. Sedap cikit bini aku peluk aku nanti. Haha (gelak). Tak cam kau. Nak sado konon. Tapi, tak laku.

\section{Analisis Semantik}

R: Ah kau. Makan cam orang kunyah tebu ja. Makan buang. Makan buang. Tak kenyang-kenyang. Kang tak muat baju kahwin nanti. Baru kau tahu. Sebab dah gemuk. Diet lah kau.

\section{Bentuk logik:}

(2) R: Ah kau. Makan cam orang

\section{Makan buang. Makan buang.}

[makan tak pernah kenyang] ja.

Tak kenyang-kenyang. Kang tak muat baju kahwin nanti. Baru kau tahu. Sebab dah gemuk. Diet lah kau.

Bagi data slanga kunyah tebu ini pengkaji memperlihatkan tahap pendekatan semantik skrip dan rasonans terlebih dahulu bagi menjelaskan secara umum makna slanga kunyah tebu di bawah analisis semantik melalui bentuk logik sesuatu makna implisit dalam sesuatu ujaran itu.

i. Semantik skrip: Bermaksud perihal seseorang yang banyak makan tetapi tidak merasa kenyang. 
ii. Semantik resonans: Dari segi kognitif, tebu merupakan sejenis tumbuh-tumbuhan yang boleh menghasilkan air yang manis dengan mengunyah batangnya kemudian hampasnya dibuang (tidak dapat makan). Ini boleh dikaitkan pemerhatian tingkah laku seseorang mendapatkan hasil (untuk minum) daripada tebu tersebut.

Walau bagaimanapun, pemberian makna bagi slanga kunyah tebu tidak terhenti di sini sahaja kerana data slanga KK yang berasosiasi dengan tumbuh-tumbuhan/buah-buahan ini akan dianalisis menggunakan pendekatan SI berdasarkan ujaran penutur dikuatkan lagi dengan RRS terhadap ujaran tersebut.

\section{Analisis Semantik Inkuisitif}

Berikut merupakan contoh penggunaan slanga kunyah tebu melalui pendekatan RRS seperti mana yang terdapat dalam transkripsi perbualan di KK.

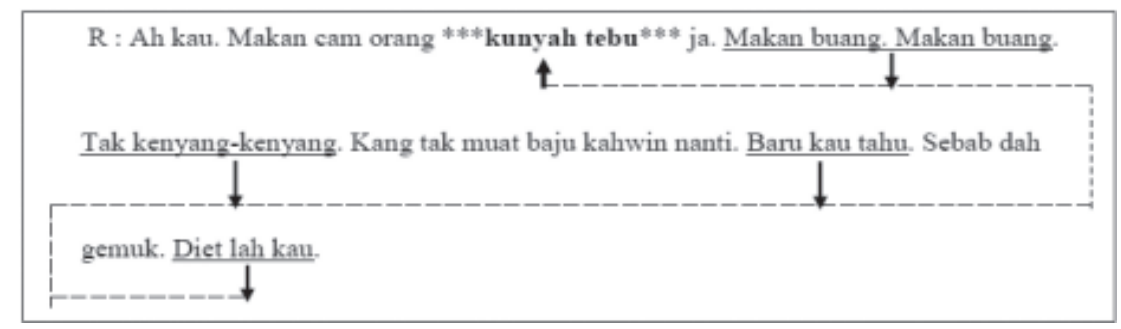

Melalui pendekatan semantik dengan menggunakan bentuk logik penutur berdasarkan ujaran transkripsi di KK pengkaji telah menganalisis slanga kunyah tebu berdasarkan sudut semantik skrip dan semantik resonans namun, analisis tersebut tidak cukup untuk menghuraikan makna sebenar sesuatu slanga itu. Oleh itu, pengkaji cuba menginterpretasikan makna sebenar slanga ini dengan mengambil kira data (transkripsi perbualan di KK), teori, kognitif, falsafah dan akal budi penuturnya untuk mencapai ke tahap SI (Nor Hashimah Jalaluddin, 2014a). 
Berdasarkan slanga di KK yang berasosiasi dengan tumbuhtumbuhan/buah-buahan leksikal tebu telah dipilih oleh penutur sebagai pembayang kepada slanga kunyah tebu seperti mana yang terdapat dalam RRS tersebut. Frasa makan buang. makan buang, tak kenyang-kenyang dan baru kau tahu merupakan kesan konteks bagi ujaran ini. Hal ini disebabkan, jika Z, makan tidak berhenti-henti bukan sahaja mendatangkan penyakit kepadanya malahan, akan menyebabkan peningkatan berat badan sehingga baju pengantin yang ditempah sebelum majlis perkahwinannya akan ketat. Oleh itu, saranan oleh $\mathrm{R}$ iaitu frasa diet lah kau telah menjadi peringatan kepada $\mathrm{Z}$ supaya mengawal permaknannya. Perkara ini telah menjadi anteseden kepada slanga tersebut yang membantu pengkaji memahami makna implisit bagi slanga tersebut.

Walau bagaimanapun, pengkaji mempersoalkan kepada pemilihan leksikal tebu bagi menggambarkan seseorang yang suka makan tapi tidak kenyang-kenyang. Berdasarkan kajian-kajian lepas Nor Hashimah Jalaluddin (2014a), ada membincangkan leksikal tebu dalam peribahasa Melayu, iaitu tanam tebu di tepi mulut. Berdasarkan kajian tersebut beliau telah mempersoalkan kenapa pemilihan leksikal tebu dan mulut digunakan dalam peribahasa tersebut yang membawa kepada tingkah laku yang negatif iaitu sikap seseorang yang membuat janji-janji manis namun, tidak ditepati. Oleh itu, bagi slanga kunyah tebu ini juga membawa makna yang konotatif kerana menggambarkan sikap seseorang yang kerap makan dan tidak kenyang-kenyang. Persoalannya, kenapa kunyah dan tebu? Kata kunyah membawa makna melumatkan (menghancurkan) makanan dalam mulut dengan gigi sebelum membuangnya/menelannya (Kamus Dewan Edisi Keempat, 2015). Kenapa tebu pula? Tebu merupakan sejenis tumbuhtumbuhan yang dapat mengeluarkan air yang manis/sedap untuk diminum namun, kenapakah kelakuan kunyah tebu ini dikaitkan dengan kelakuan negatif seseorang yang tidak dapat mengawal nafsu makanannya.

Bagi slanga kunyah tebu ini leksikal kunyah tidak perlu diberi perincian makna yang mendalam bagi pengkaji. Hal ini demikian kerana leksikal kunyah merupakan anteseden sebelum leksikal tebu 
yang merupakan kata kerja yang menerangkan kelakuan seseorang mengunyah tebu. Namun, pengkaji mempersoalkan kenapa pemilihan tebu digunakan oleh penutur sebagai pembayang kepada slanga ini sedangkan banyak lagi tumbuh-tumbuhan/buah-buahan lain yang mampu menggantikan tempat tebu tersebut. Dengan itu, di sinilah perlunya pendekatan SI untuk menjawab persoalan tersebut. Persoalan leksikal tebu ini dirujuk berdasarkan kajian Nor Hashimah Jalaluddin (2014b), yang memperhatikan struktur tebu yang mempunyai daun yang tajam, kasap/miang dan mempunyai kulit yang keras dan liat namun, menghasilkan air yang manis dan enak rasanya. Dengan rasa yang manis dan enak rasanya tebu mampu menghasilkan air.

Cara penghasilan air tebu boleh dihasilkan melalui dua cara, iaitu secara praktikalnya menggunakan mesin tebu manakala, secara manualnya menggunakan kaedah mengunyah menggunakan gigi untuk mendapatkan airnya yang manis dan enak itu dan kemudiannya hampas tebu tersebut dibuang. Dapat melihat kesinambungan kepada slanga kunyah tebu tersebut makna yang hendak disampaikan oleh penutur pada mula-mula yang dibincangkan pada awal analisis iaitu sikap seseorang makan tak pernah kenyang. Hal ini demikian kerana dengan mengunyah tebu tersebut tidak mampu memberikan kekenyangan kepada seseorang itu tetapi, mampu menghilangkan rasa haus. Berbalik pula pada frasa makan buang. makan buang seperti mana yang terdapat pada RRS telah menunjukkan kelakuan normal seseorang yang akan makan dan kemudiannya membuang air besar secara implisit nya kerana penutur menghormati konteks di kedai makan/KK dan menggunakan eufemisme bagi menggantikan kata berak/membuang air besar. Hal ini berkaitan dengan hal kebencian yang dimaksudkan dalam masyarakat tersebut adalah mengenai persepsi terhadap orang di sekeliling mereka yang mempunyai sifat atau perangai buruk dan juga mengenai kekotoran (Muhammad Zaid Daud, Mohammad Shahrul Nizam Abd Wahid, Remmy Gedat, 2017, 2018). 


\section{Slanga: Mat Jambu}

\section{Lokasi: Kedai Kopi Haji Man, Kuala Lumpur}

R: Wehh. Kau free ja kan. Aku nak minta tolong kau. Teman aku pergi sekolah. Kasi kad kahwin aku kat cikgu-cikgu.

J: Ok boleh ja. Haha (gelak). Mesti cikgu-cikgu tu terkejut dapat tau kau dah nak kahwin. Mat jambu sekolah lah kata kan. Budak hot. Semua orang kenal.

R: Mana tak nya. Dak yang selalu ponteng kelas. Panjat pagar sekolah nak kahwin.

J: Haha (gelak). Tak pa la. Tu kisah silam. Jangan di kenang. Untung la kau. Muda-muda lagi dah kahwin. Aku ni tak de jodoh lagi.

\section{Analisis Semantik}

J: Ok boleh ja. Haha (gelak). Mesti cikgu-cikgu tu terkejut dapat tau kau dah nak kahwin. Mat jambu sekolah lah kata kan. Budak hot. Semua orang kenal.

\section{Bentuk logik:}

(iii) B: Ok boleh ja. Haha (gelak). Mesti cikgu-cikgu tu terkejut dapat tau kau dah nak kahwin. sekolah lah kata kan.

[Lelaki yang mempunyai perwatakan/rupa paras menarik] Budak hot. Semua orang kenal.

Konteks memainkan peranan penting dalam pemberian makna slanga ini. Makna ditapis berdasarkan analisis semantik dan bentuk logik terlebih dahulu sehingga dapat mencungkil makna implisit di sebalik pembentukan slanga tersebut. Oleh itu, makna mudah bagi slanga mat jambu merujuk kepada seseorang lelaki yang mempunyai perwatakan/rupa paras yang menarik/menjadi kegila-gilaan kepada seseorang.

\section{Analisis Semantik Inkuisitif}

Seperti setiap permulaan analisis SI pengkaji menggunakan pendekatan RSS bagi mencungkil makna sebenar sesuatu slanga itu berdasarkan 
RRS merupakan maklumat tambahan yang boleh membantu pembaca memahami maksud yang hendak disampaikan oleh penutur iaitu mat jambu. Berikut merupakan RRS daripada transkripsi perbualan di KK bagi slanga tersebut.

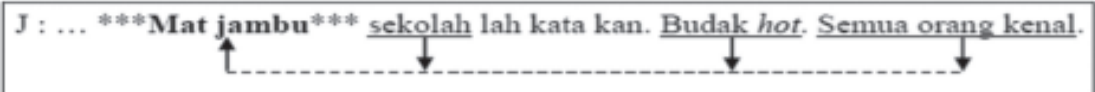

Pemberian makna bagi slanga Mat Jambu ini telah diperoleh daripada analisis semantik - bentuk logik lagi, iaitu dengan membawa maksud seseorang lelaki yang mempunyai perwatakan/rupa paras yang menarik/menjadi kegila-gilaan kepada seseorang. Makna slanga tersebut juga dikuatkan lagi dengan analisis RRS sebagai maklumat tambahan yang merupakan anteseden kepada slanga Mat Jambu tersebut. Dengan itu, merujuk kepada RRS tersebut leksikal kata nama sekolah serta frasa Budak hot dan semua orang kenal telah menambahkan lagi bukti kepada pengkaji untuk menyingkap makna sebenar slanga tersebut. Hal ini demikian kerana leksikal sekolah telah merujuk kepada sesuatu tempat yang besar yang menjadi tempat para pelajar lelaki dan perempuan untuk mendapatkan pendidikan yang formal. Pada masa yang sama sekolah jugalah tempat untuk para pelajar untuk menonjolkan diri mereka untuk dikenali oleh rakanrakan lain mahupun, dalam kalangan guru-guru. Oleh itu, frasa Budak hot dan semua orang kenal merupakan sokongan kepada data tersebut.

Namun begitu, analisis ini tidak berhenti di sini sahaja kerana pengkaji perlu mempersoalkan kenapa pemilihan objek dan imej bagi sesuatu slanga itu. Bagi data slanga ini Mat merupakan objek manakala jambu merupakan objek tambahan bagi slanga ini. Seperti sedia maklum nama panggilan Mat begitu sinonim dengan lelaki terutama seseorang yang bernama Mamat, Ahmad dan sebagainya. Walau bagaimanapun, wujud persoalan pengkaji kenapa pemilihan buahbuahan jambu dipilih bagi mewakili objek slanga tersebut untuk merujuk kepada lelaki yang mempunyai rupa paras/perwatakan yang menarik. Secara saintifiknya nama jambu merupakan Syzygium samarangense yang mudah diperoleh di pasar basah dan pasar raya. Buah jambu juga merupakan salah satu buah-buahan yang senang didapati di Malaysia atau negara-negara beriklim tropika. 
Namun demikian, apakah kaitannya jambu air tersebut bagi merujuk makna kepada seseorang lelaki yang mempunyai perwatakan/ rupa paras yang menarik/menjadi kegila-gilaan kepada seseorang. Seperti yang sedia maklum leksikal Mat telah menerangkan ia merujuk kepada lelaki namun, kaitan paras yang menarik/menjadi kegila-gilaan kepada seseorang terutama wanitalperempuan dengan jambu tersebut masih belum terjawab.

Bagi menjawab kepada persoalan tersebut pengkaji melihat kepada warna jambu air tersebut yang sudah tentu berwarna merah dan begitu menarik perhatian manusia mahupun haiwan. Tambahan pula, bahasa kiasan tidak akan lari daripada unsur alam kerana hal ini meliputi sifat, kategori dan tabiat umum tumbuh-tumbuhan itu sendiri dan mampu menjadi objek pembayang kata bagi sesuatu bahasa kiasan tersebut (Nor Hashimah Jalaluddin, 2015). Oleh itu, masyarakat Melayu khususnya bijak menggunakan unsur alam untuk menggantikan sesuatu ujaran yang mampu melukai hati pendengar. Pengkaji turut mengaitkan dengan warna merah jambu ( $p i n k)$ yang sememangnya menjadi kegilaan/kegemaran gadis-gadis kerana warnanya yang lembut dan bersifat feminin jika digayakan oleh golongan wanita. Dapat dirumuskan bahawa, slanga mat jambu yang membawa makna yang telah dianalisis sebentar tadi telah terjawab.

\section{Slanga: Jua Langsat (DMK) \\ Lokasi: Kedai Kopi Abe Salleh}

A : Kito tunggu ngoh kat kedai abe se la weh.

B : Hom lah. Dop tau Ngoh bilo nok sampai.

A : Tu loh. Payoh nok beruruse denge ngoh sore nim. Jenis ore jua langsat payoh nak caro. Dok tau mane kepalo eko. Sesak merato jah.

\section{Analisis Semantik}

Bentuk logik:

Tu loh. Payoh nok beruruse denge Ngoh sore nim. Jenis ore payoh nak caro. Dok tau mane kepalo eko. Sesak merato [singgah merata-rata tempat] 
Bagi slanga KK jua langsat (jual langsat) agak rumit untuk dianalisis menggunakan analisis semantik melalui bentuk logik ini. $\mathrm{Hal}$ ini demikian kerana penggunaan objek dan imej yang digunakan oleh penutur agak kabur untuk dianalisis pada peringkat ini. Oleh itu, pengkaji akan membawa data slanga jua langsat ini terus kepada analisis SI. Walau bagaimanapun, makna mudah bagi slanga ini adalah seseorang yang selalu singgah merata-rata tempat berdasarkan konteks perbualan A dan B.

\section{Analisis Semantik Inkuisitif}

Slanga di KK yang mempunyai asosiasi dengan tumbuh-tumbuhan/ buah-buahan adalah jua langsat (DMK) yang menggabungkan kata kerja, iaitu jua (menjual) dengan kata nama merujuk kepada buahbuahan iaitu langsat. Pengkaji sudah memberikan makna mudah bagi slanga tersebut menggunakan melalui pendekatan semantik bentuk logik sebentar tadi. Walau bagaimanapun, makna mudah yang membawa makna seseorang yang tidak tepati masa dan sering singgah merata-rata tempat sebelum sampai ke destinasi adalah tidak mampan untuk diberikan perincian makna sebegitu. Oleh itu, pengkaji akan merungkai makna sebenar slanga tersebut melalui RRS terlebih dahulu dengan mengaitkan konteks di dalam perbualan tersebut.

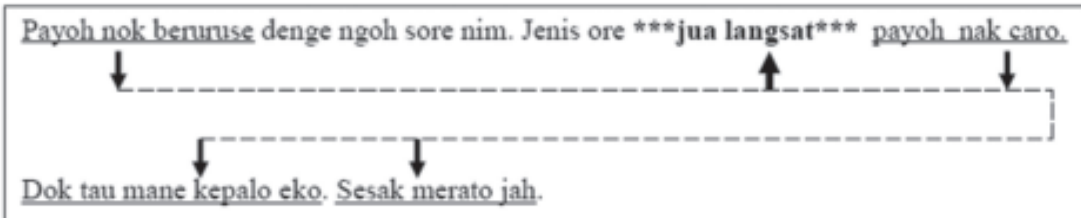

Berikut merupakan contoh data ujaran yang terdapat dalam transkripsi perbualan, iaitu bagi slanga jua langsat yang dapat membantu menerangkan maksud sebenar slanga tersebut. Dalam frasa payoh nok beruruse, payoh nok caro, dok tau mane kepalo eko dan sesak merato jah telah menunjukkan sikap seseorang yang tidak boleh dipercayai terutama dari segi masa. Frasa-frasa tersebut telah menjadi maklumat tambahan yang membantu pengkaji memahami maksud sebenar yang hendak disampaikan oleh penutur, iaitu menggunakan 
istilah jua langsat bagi merujuk seseorang yang tidak tepati masa dalam berjanji malahan sering singgah di merata-rata tempat terlebih dahulu sebelum sampai ke destinasi.

Walau bagaimanapun, wujud persoalan bagi pengkaji mengapakah slanga jua langsat ini diberikan pendefinisian makna sebegitu atau membawa makna yang konotasi sedangkan aktiviti menjual buahbuahan seperti langsat adalah sesuatu pekerjaan yang amat baik malahan dapat menambahkan pendapatan seseorang itu. Oleh itu, beginilah sebabnya perlunya pendekatan SI untuk menjawab persoalan ini. Hal ini demikian kerana melalui pendekatan SI ini pengkaji perlu meneroka jawapan sebenar pemilihan objek dan imej dalam slanga tersebut yang dapat menonjolkan akal budi penutur apabila mengujarkan slanga tersebut.

Masyarakat di negeri Kelantan begitu terkenal dengan sikap suka berniaga sama ada secara kecil-kecilan mahupun besar-besaran. Melihat sahaja di kawasan seperti Bazar Buluh Kabu, Pasar Borong Wakaf Che Yeh, Pusat Perniagaan Zon Bebas Cukai Rantau Panjang KB Mall, Zon Bebas Cukai Pengkalan Kubur, Bazar Tok Guru dan KB Bazar rata-ratanya memperlihatkan kepesatan ekonomi perniagaan oleh masyarakat Kelantan yang suka berniaga (Rosniza Aznie Che Rose, Nurul Fatihah Jusoh, Rosmizah, Lyndon dan Mokhtar, 2015). Namun begitu, kenapakah penutur mengaitkan slanga jua langsat dengan membawa makna yang konotatif. Baiklah pengkaji akan merungkai sebab-sebab pemilihan leksikal tersebut. Pertamanya kita melihat kepada sifat seseorang yang ingin menjual buah-buahan yang ringan seperti langsat, duku, ciku dan sebagainya. Untuk menambahkan pendapatan seseorang peniaga barang-barang tersebut tidak akan duduk di satu tempat sahaja untuk menjual buah-buahan tersebut dan cuba untuk bertukar-tukar tempat untuk menjual. Oleh sebab, penjual buah-buahan itu berniaga dari satu tempat ke sesuatu tempat penutur bijak membuat perumpamaan dengan menyifatkan seseorang yang sering singgah di merata-rata tempat terlebih dahulu sebelum sampai ke destinasi. 


\section{Rumusan}

Kesimpulannya, penciptaan ungkapan slanga bukanlah secara sewenang-wenangnya kerana wujudnya falsafah dan akal budi penciptaannya yang tersendiri. Makna yang terkandung dalam sesuatu perkataan yang dikatakan slanga itu ada kalanya bersifat tersirat dan memerlukan interpretasi makna yang mendalam untuk memahami sesuatu perkataan tersebut. Oleh itu, perincian makna secara saintifik dapat dikemukakan berdasarkan pendekatan semantik inkuisitif di samping akal budi penutur di sebaliknya. Kombinasi ini adalah sangat penting bagi menjelaskan falsafah di sebalik objek tumbuhan yang digunakan oleh penutur dalam pembentukan slanga tersebut.

Seperti dimaklumkan pada awal penulisan tadi, kajian yang mengaplikasikan pendekatan semantik inkuisitif ini lebih terarah kepada data peribahasa dan cerita lipur lara. Dapatan kajian sebelum ini, diperoleh daripada sumber bertulis atau dokumen yang telah dibukukan. Berbeza pula, dengan kajian ini kerana data melibatkan data primer kerana data diperoleh secara langsung dari sumber asli atau pihak pertama melalui audio perbualan tidak formal. Meskipun pengkaji menggunakan data slanga sebagai bahan kajian untuk menganalisis kajian ini pengkaji turut mengaplikasikan data, teori, kognitif dan akal budi atau intelektual Melayu seperti mana yang telah disenaraikan oleh Nor Hashimah Jalaluddin (2014a). Kajian slanga yang mengaplikasikan pendekatan semantik inkuisitif adalah kurang dijalankan oleh pengkaji yang lepas. Kajian ini dapat dijadikan lonjakan dan rujukan kepada pengkaji terkini dalam menganalisis slanga menggunakan pendekatan semantik inkuisitif.

\section{Bibliografi}

Aboh, R. (2015). Slang and multiple methods ff interpreting sex and sexual identity in the Nigerian novel. The African Symposium: An Online Journal of the African Educational Research Network, 15(1). 
Ajid Che Kob. (1998). Gah bahasa: Beberapa persoalan yang menghambat bahasa Melayu. Pengajian Melayu Memasuki Alaf Baru. Kuala Lumpur. Akademi Pengajian Melayu, Universiti Malaya.

Arua, E. A., \& Modupe, M. A. (2009). The Creation of students' academic slang expressions in the University of Botswana. Linguistic Online, 4(9).

Asmah Haji Omar. (1993). Bahasa Malaysia saintifik. Kuala Lumpur. Dewan Bahasa dan Pustaka.

Brooke, I. (1973). English costume in the age of Elizabeth: The sixteenth century. London. Adam \& Charles Black.

Kamus Dewan Edisi Keempat. (2015). Kuala Lumpur. Dewan Bahasa dan Pustaka. Author.

Gan, K. L. (2000). Strategi penukaran kod di kalangan guru-guru Cina Berpendidikan Cina dan Bukan Berpendidikan Cina: Satu Kajian Kes. Tesis Sarjana. Universiti Malaya.

Indrawati Zahid. (2012). Bahasa Melayu terpinggir dalam media baharu? Dewan Bahasa. Kuala Lumpur.

Inhorn, M. C. (2004). Middle Eastern Masculinities in the Age of New Reproductive Technologies: Male Infertility and Stigma in Egypt and Lebanon. Medical Anthropology Quarterly, 18(2).

Junaini Kasdan, \& Nor Hashimah Jalaluddin. (2015). Unsur asam dan akal budi Melayu: Analisis Semantik Inkuisitif. Dalam Seminar Meja Bulat: Simpulan Bahasa dan Kognitif Penutur (pp. 1-20). Kuala Lumpur: Institut Alam dan Tamadun Melayu (ATMA), Universiti Kebangsaan Malaysia.

Junaini Kasdan, Nor Hashimah Jalaluddin, \& Wan Nurasikin Wan Ismail. (2016). Ikan (Pisces) dalam Peribahasa Melayu: Analisis Semantik Inkuisitif. International Journal of the Malay World and Civilisation (Iman), 4(1). 
Kempson, R. M. (1986). Ambiguity and the semantics and pragmatics distinction. Dlm. C. Travis (Ed.), Meaning and interpretation. Oxford: Basil Blackwell.

Kheren Kezia Adolof. (2014). Slang dalam lagu Black Eyed Peas. Tesis Sarjana. Universitas Sam Ratulangi, Indonesia.

Mary Fatimah Subet, \& Muhammad Zaid Daud. (2016). "Giler" atau "Gile": Slanga Kata Penguat. Jurnal Bahasa, 16(2).

Mary Fatimah Subet, \& Muhammad Zaid Daud. (2017). Semantik dan makna konotasi dalam slanga pelacur. Kertas Kerja ini dibentangkan semasa The International Conference on Language Studies (iCLS) 2017, Kuching (Riverside Majestic Hotel). 9-10 Ogos 2017.

Mary Fatimah Subet, \& Muhammad Zaid Daud. (2018). Makna denotatif dan konotatif dalam slanga pelacur. MALTESAS MultiDisciplinary Research Journal (MIRJO), 3(1), 29-43.

Mhd. Amin Arshad. (2000). Bahasa slanga: Pembentukan dan ciricirinya dalam Monograf Bahasa, Sastera, dan Budaya Melayu. Serdang, Selangor: Universiti Putra Malaysia.

Mohd Faizal Musa. (2014). Beberapa nota kearifan Melayu tentang sakit tuan: Satu pengenalan. International Journal of the Malay World and Civilisation (Iman), 2(3).

Mohd Ismail Tambi. (1995). Pengenalan dan rawatan sakit tuan. Kuala Lumpur: Utusan Publications and Distributors Sdn. Bhd.

Mohd Ridzuan Md Nasir, \& Mary Fatimah Subet. (2019). Inovasi pengajaran dan pembelajaran peribahasa Melayu menggunakan Semantik Inkuisitif. MALTESAS Multi-Disciplinary Research Journal (MIRJO), 3(3).

Muhammad Zaid Daud, \& Mary Fatimah Subet. (2019a). Ayam (Gallus Gallus Domesticus) dalam peribahasa Melayu: Analisis semantik inkuisitif. Jurnal Kemanusiaan, 17(1). 
Muhammad Zaid Daud, \& Mary Fatimah Subet. (2019b). "Sudah tidak tersudu oleh angsa, baru diberikan kepada itik": Perspektif Semantik Inkuisitif dan Akal Budi Melayu. Jurnal Melayu Sedunia, 2(1).

Muhammad Zaid Daud, Mohammad Shahrul Nizam Abd Wahid, \& Remmy Gedat. (2017). Eufemisme dalam bahasa Iban: Satu kajian kes di Kampung Lebor, Serian, Sarawak. Borneo Research Journal, 11(1).

Muhammad Zaid Daud, Mohammad Shahrul Nizam Abd Wahid, \& Remmy Gedat. (2018). Penggunaan eufemisme dalam kalangan penutur Iban. International Journal of Language Education and Applied Linguistics (IJLEAL), 8(1).

Muhammad Zaid Daud. (2017). Slanga kedai kopi: Satu analisis semantik inkuisitif. Tesis Sarjana Muda. Universiti Malaysia Sarawak, Malaysia.

Muhammad Zaid Daud. (2018a). Domain rezeki dalam peribahasa Melayu Berorientasikan Aves Melalui Perspektif Semantik Inkuisitif. MALTESAS Multi-Disciplinary Research Journal (MIRJO), 3(1).

Muhammad Zaid Daud. (2018b). Gallus gallus domesticus dan paradoxurus hermaphroditus dalam peribahasa Melayu: Analisis semantik inkuisitif. Sains Humanika, 10(2).

Muhammad Zaid Daud. (2018c). Pengaplikasian kerangka semantik inkuisitif melalui slanga. MALTESAS Multi-Disciplinary Research Journal (MIRJO), 3(3).

Nadiah Suboh. (2013). Aspek bahasa Melayu dalam penulisan blog berdasarkan Perisisan Pengukuran NEMD Versi 2.0. Tesis Sarjana. Universiti Putra Malaysia, Serdang, Malaysia.

Nor Hashimah Jalaluddin. (2014a). Semantik dan akal budi Melayu. Bangi: Penerbit Universiti Kebangsaan Malaysia. 
Nor Hashimah Jalaluddin. (2014b). Pemugaran penyelidikan untuk pemerkasaan bahasa. Institut Alam dan Tamadun Melayu, Universiti Kebangsaan Malaysia.

Nor Hashimah Jalaluddin. (2015). Peribahasa 'parasit' dan akal budi Melayu: Analisis semantik inkuisitif. Dalam Seminar Bahasa dan Sastera 2015 (pp. 281-293). Bangi: Pusat Pengajian Bahasa dan Linguistik, Universiti Kebangsaan Malaysia.

Nur Afiqah Wan Mansor, \& Nor Hashimah Jalaluddin. (2015). Deria rasa dalam kiasan Melayu: Analisis semantik inkuisitif. Journal Pertanika Mahawangsa, 2(1).

Nur Afiqah Wan Mansor, \& Nor Hashimah Jalaluddin. (2016). Makna implisit bahasa kiasan Melayu: Mempertalikan komunikasi, kognisi dan semantik. Jurnal Komunikasi, 32(1).

Rosniza Aznie Che Rose, Nurul Fatihah Jusoh, Rosmizah, M. Z., Lyndon, N., \& Mokhtar, J. (2015). Perkembangan dan cabaran sektor perniagaan sebagai pemangkin pembangunan bandar kecil: Kajian empirikal di Daerah Besut, Terengganu. GEOGRAFIA OnlineTM Malaysian Journal of Society and Space, 11(8).

Sara Hashemi Shahraki, \& Abbass Eslami Rasekh. (2011). Check this one out: Analyzing slang usage among Iranian male \& female teenagers. English Language Teaching, 4(2).

Setiawan Nugroho. (2015). Pembentukan kosakata slang dalam komunitas jkboss Pada Akaun Twitter @JakartaKeras. Tesis Sarjana. Universitas Negeri Yogyakarta, Indonesia.

Siti Hajar Abdul Aziz. (2008). Bahasa Melayu I. Shah Alam: Oxford Fajar.

Surati Zakaria, \& Nor Hashimah Jalaluddin. (2016). Konsep ruang dalam anggun Cik Tunggal: Analisis semantik inkuisitif. GEMA Online ${ }^{\circledR}$ Journal of Language Studies, 16(3).

Tangaprabu, Murthy, Mary Fatimah Subet. \& Muhammad Zaid Daud. (2019). Kajian semantik inkuisitif dalam peribahasa Tamil: Imej Tumbuhan. Sains Humanika, 11(1). 
Tangaprabu, Murthy, \& Mary Fatimah Subet. (2018a). Imej rumput dalam peribahasa Tamil: Suatu kajian semantik inkuisitif. Issues in Language Studies, 7(1).

Tangaprabu, Murthy, \& Mary Fatimah Subet. (2018b). Imej tebu dalam peribahasa Tamil: Analisis semantik inkuisitif. Trends in Undergraduate Research, 1(1).

Tay, M. G. (2010). Analisis linguistik terhadap penggunaan bahasa SMS dalam kalangan guru pelatih. Jurnal Penyelidikan IPG Kampus Batu Lintang, 10, 1-26.

Wespes, E., Amar, E., Hatzichristou, D. G., Montorsi, F., Pryor, J., \& Vardi, Y. (2002). Guidelines on Erectile Dysfunction. Eur Urol Journal, 41(1).

Zhou Y., \& Fan Y. (2013). A sociolinguistic study of American slang. Theory and Practice in Language Studies, 3(12).

Zuraidah Mohd Sulaiman, Gan Kiat Chien, Eng Sze Boon, \& Ahmad Harith Syah Md Yusuf. (2012). Slanga remaja Melayu dan Cina: Analisis awal berdasarkan Teori Relevan. International Conference On Arts, Social Sciences, And Technology (ICAST2012). 